\title{
Multicultural Responsive Interpretation
}

\author{
Ahmad Haromaini \\ \{aharomaini@unis.ac.id\} \\ Universitas Islam Syekh-Yusuf Tangerang
}

\begin{abstract}
Humans are created not uniform, both race, tradition and even religion. This diversity on the one hand can be regarded as an asset but on the other hand has the potential to trigger conflict. Conflicts that are motivated by religion are investigated stemming from the reading of religious texts, in this case the Qur'an and its interpretation. The interpretive explanations presented do not pay attention to aspects of multicultural community diversity. If the text that is read becomes a problem, then how does the role of the interpreter explain the verses of the Koran by taking into account the conditions of certain communities which were created differently from the beginning? Then whether the interpretation that has been done by the interpreter has responded to multiculturalism? Multicultural interpretation becomes an answer for people who live with different cultures. Based on this background the research was conducted aimed at building a new paradigm of interpretation by explaining the verses of the Qur'an that explain about humans by considering different social aspects of society. Because according to Komaruddin Hidayat the content and direction of a work will be influenced by its social aspects.
\end{abstract}

Keywords: Al-Qur'an, Interpretation, Multicultural.

\section{Introduction}

Humans are created equipped with the potential to create harmony. God equips man with various devices that can help him create peace. The peace it creates is not only directly related to each other, but also related to the surrounding environment. The Qur'an as a sacred text refers to humans as al-insan. One term that in the tradition of interpretation is understood as being endowed with in itself the qualities of harmony [1].

A pluralistic society is God's will. The plural society is in accordance with His will, given, taken for granted (QS. 5:48). Because there is no one chance for humans to make choices as a society that is uniform in terms of ethnicity, nation or religion. They are born according to the environment and the type of nation of the parents who gave birth. This diversity is something that cannot be avoided. Because God who has the sole role of making humans different. Though at first they were created from one type (QS. 4:1).

Multiculturalism is understood as a condition including people from different races, religions, languages and traditions [2]. This difference becomes an inevitability of humans. This diversity is on the one hand an asset but also has the potential for conflict between them.

As the definition above, diversity does not occur only in the physical matter of humans, but also in the matter of beliefs that they determine in their lives. Differences in beliefs can also be a problem that has the potential for friction between fellow believers. The problem of ethnic and religious diversity always colors a long history of conflicts that occur between 
fellow believers. Nurcholis Madjid is of the view that it is necessary to create a dialogical space between fellow believers and followers of other religions [3]. Because the harmony of a nation is everyone's hope.

In addition to opening a dialogical space, its relationship with Islam, a believer must be able to have a good understanding of religious texts that have taught them the importance of building harmony both internally within Muslims and to adherents of other religions. Because after all humans in principle have the potential to create harmony that God has given him. From this term al-insan have the responsibility and strategic role of creating harmony.

Al-Qur'an texts mention the human term by the mention of al-insan. Beginning with regard to their creations of one type and then multiplying into humans with large numbers (QS. 4:1), categorization of groups capable of optimizing time well (QS. 103:2), to the necessity of them being aware of diversity by requiring them to know one another in the human frame (QS. 49:13).

But the ideal conditions of the plurality of a nation are not always directly proportional to the desired expectations. There are still frequent conflicts between ethnic, ethnic and even religious groups. Conflicts based on diversity often occur. Even disturbing actions to acts of terror that arise are often experienced by those who are different from other people's beliefs. What is sad about all these terrorist acts is that the actions carried out are believed to be present in the spirit of their belief in religion which originates from a narrow religious understanding that makes them negate the existence of followers of other religions.

The issue of understanding religion does not stop there. Even the authorities may interpret religious teachings for the ambition of power they desire and maintain. This mindset, according to M. Quraish Shihab is considered to have influenced the majority of muslims [4]. He further called this kind of action a mistake in understanding religion. Because religious teachings are not positioned as a text and teachings that should be understood objectively without any particular interests of those who understand them. This misunderstanding can be called the misunderstood religion [4].

As an asset, the plurality of a nation must be understood as a wealth that becomes a very rich material to be explained in a product of interpretation. But is the wealth that God has created can be understood and explained properly? Then whether the interpretation that has been done by the interpreter now has responded to multiculture? Problems like these deserve to be discussed and explained comprehensively. Because the understanding of the correct text impacts on the correct understanding and the reward of all that is the realization of a harmonious and harmonious society in accordance with the nature of humanity itself which has the potential to create harmony.

This paper is motivated by a number of things that have been mentioned. The author tries to explain how to create peace in the life of the nation with a plural society with the spirit of a peaceful and tolerant text. This short article is taken from what Muhammad Abduh has done in developing commentary work in the form of adab al-ijtima'I. This style seeks to link the purpose of the verse with the natural laws that apply in society [5].

The purpose of this paper is to build intellectuals based on Islamic content produced from interpretive products that have the values of peace. The method was adopted by building a new paradigm of interpretation based on a multicultural perspective. If the distribution of Islamic content received by the public is influenced by a superficial understanding of religious texts, especially those related to the reality of a multicultural society will certainly give birth to conditions that display intolerant social conditions, vulnerable to social conflict. Because it needs to be built intellectuals who have a soul tasamuh, tolerant and have a good acceptability 
of differences. It is impossible to discuss the orientation of strengthening religious harmony, especially without understanding the map of religious harmony in the intellectual map [6].

\section{Research Methods}

This study used qualitative research methods. Bogdan and Taylor as quoted by Lexy J. Moleong said that qualitative research is research that produces descriptive data in the form of written or oral words that originate from the words and actions of a person observed by the researcher [7]. The author collects written data in this case are verses relating to humans relating to the sociological aspects and supported by sources of classical interpretation.

\section{Al-Qur'an as a Text Of Peace}

As a holy book, the Qur'an is believed by Muslims to be the verbum dei, the word of Allah. delivered to the prophet Muhammad PBUH. Through the angel Gabriel [8]. Aside from being the word of God, al-Qur'an also serves to justify Muhammad's troubles. The texts that he delivered not only conveyed divine messages but also as strong evidence for the prophet Muhammad. in carrying out God's commands [9].The history of Arabic civilization records the existence of the Qur'an as being considered a central text [10]. The Qur'an is present in the midst of a nation that has a very good text tradition. Even when it was revealed by the civilization of the text they had built it had reached its peak. The greatness of Arabic at that time was because it had a very good arrangement of language beauty [11].

Fazlur Rahman considers that the main goal of the Koran is to establish a just society based on ethics, and the Koran is able to survive throughout human life on earth [12]. AlQur'an denounced the efforts made in the form of social injustice against the community that occurred in the city of Mecca [12]. The spirit of the Koran in building a just and egalitarian society needs to be voiced in the form of an interpretive text that also has the same spirit.

The spirit that is built by the Koran is not only in relation to justice in society, but that spirit is also built in the efforts taken by the Koran to ban one action that leads to an intolerant attitude towards all groups of people. Al-Qur'an's verses pretty much explain the relation of human life, both fellow Muslims and adherents to other religions. The instructions for creating a peaceful life have been conveyed by the Koran, to the prohibition of the Koran not to revile the worship of other religions. In QS. Al-An'am : 108

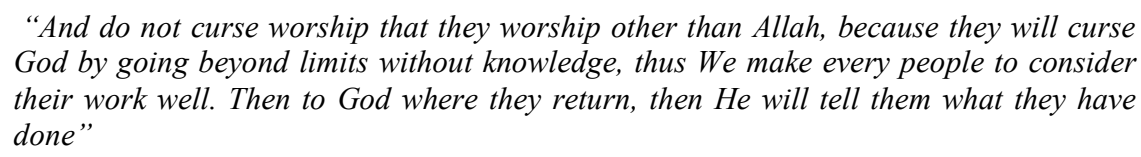

This verse expressly forbids believers from taking actions that offend other believers. It could happen the opposite is done from them to the believers, they revile Allah swt. The prohibition conveyed is actually to be addressed by not doing such acts. Because if cursing to the worshipers of other religions will result in similar actions taken from them to Muslims so that actions will occur that can trigger disharmony in the life of the nation and state. From this verse it should be understood as an understanding which states that an act which triggers disobedience must be abandoned and every act that gives rise to an adverse effect then it becomes forbidden [13]. 
The act of cursing the worship of others, even though it is believed there is a benefit, but the damage caused is far greater. Avoiding damage for the sake of getting more priority first. Therefore Allah Almighty. forbid the prophet Muhammad. do such an action [14]. Prohibition of Allah Almighty. to the prophet Muhammad. actually applies to the next believers. Therefore it is not justified or taught to people of faith whether they have the role of Islamic propaganda or do not do such actions. As a religion that carries messages of peace, Islam teaches its adherents and all people to look after one another and respect the beliefs and religions of others.

Maintaining peace in the midst of religious plurality must be maintained well. Moreover, countries on the Asian continent become continents that have a level of diversity that is so complex. Even so the spirit of tolerance is well developed through the establishment of places of worship in the middle of their lives. This condition was later called by Anthony Reid to be a large laboratory for the continuation of religious pluralism [15].

Overcoming conflicts that cracks peace is not only focused on relations of different beliefs and relates to followers of other religions. However, this conflict often arises within the Muslims. Settlement of the conflict disputes required reconciliation between them (QS. 49:910). The effort was taken considering that Islam does not want an unharmonious atmosphere preserved in the lives of every Muslim.

In addition, the efforts of the Qur'anic text create peace regarding equality. The Qur'an firmly states that every individual human being with any kind of race has an equal position before God. Even with the al-Qur'an firmly erase the forms of attitude that distinguishes humans except with devotion [12]. Devotion is a fundamental quality of one's glory before God. With the instructions of the text, the interpretation of the Qur'an has a strategic role in creating a spirit of equality through texts that are built and developed from the text of the Qur'an.

\section{Interpretation of Multicultural Patterns, Solutions to Respond to Plurality}

Interpretation is understood as a result of the first text, its existence being a solution in understanding the content of the Qur'anic text [16]. As an activity explaining the content of the Qur'an, efforts to respond to social aspects become a necessity. One that can be taken as an example of applying social response is the response of the Qur'an to the developing socialsocial civilization, namely the miracle of the Qur'an. Allah SWT. provide miracles to His messengers in accordance with the context of progress and civilization that develops in society. The suitability of the miracle is considered to be something very fair for the continuation of the propaganda of the prophets [17]. Because after all this suitability can facilitate the public to understand the messages of the prophet delivered. Because if it is not appropriate, it will be difficult for them to revitalize the context of miracles with the reality they face.

On the issue of the miracle of contextualization, it has already occurred. Therefore the context of interpretation can also be done by responding to social situations such as those carried out by Hassan Hanafi. For him classical Islamic science needs to respond to the condition of the Islamic Ummah that is happening [18]. Interpretation in Islam becomes a scientific tradition that continues to experience its development. Actually the tradition of interpreting the text of the Qur'an not only departs from outside the text, but internally the text 
itself. Where between verses with other verses can interpret each other[19]. In its concrete form, interpretation has begun to occur since the time of the Prophet Muhammad. because in essence the prophet Muhammad. as the first and foremost interpreter of all the texts that God delivered to him [19]. At that time the prophet Muhammad. as a single interpreter.

In addition to the miracles of the Qur'an, the relation of the text to reality is revealed asbab al-nuzul, the science that discusses the close relationship between the text and reality. It is considered very important to understand because it can help the interpreters explain the intended purpose of the verse by paying attention to the socio-cultural response of the text. Between text and reality, dialogues and dialectics are developed [10]. Even Nasr Hamid Abu Zaid asserted that every verse or number of verses were revealed there was a special reason that required it to be revealed Abu Zayd.

Understanding universal texts such as the Qur'an is indeed not enough to rely solely on the socio-cultural aspects of Arab society, the first people to witness the Qur'anic text descend. This universal text must in fact be able to explain the reality that has been built on people who have not directly witnessed the Qur'an being revealed. This effort was carried out in a way that it was understood and practiced by the early generations when it was first descended, but at the same time it could be practiced in a modern context [20].

Universality of al-Qur'an can actually explain the needs of the community in answering the problems it faces. Even though it is different in culture, the spirit of the text of the Qur'an applies to everything. The guidance that the Qur'an possesses is not only for those who believe (QS. 2:2), but also for all people on earth. That is why in any condition and situation the relevance of the Qur'an will be maintained and have a value of validity that never subsides.

Hassan Hanafi mentioned that since the presence of Islam on the face of the earth, the activities of explaining the Qur'an became part of the intellectual activities of Islamic scholars [21]. However, the movement of interpretation of the Qur'an is always related to the spirit of the times and the system of power that was taking place at that time [21]. Muhammad Abduh just mentioned that what motivated the writing of the interpretation of Al-Manaar was the people's desire for a comprehensive understanding of the Qur'anic texts [22]. Because it is possible to build a new paradigm of interpretation with a multicultural style becomes very important to do.

As a noble move, the position of interpretation for Muslims is needed [16]. Expressing the beauty of the Qur'an becomes very important. Therefore the interpretation of the texts of the Koran must indeed continue in accordance with the spirit and needs of the times. But still according to the author, it should also pay attention to the social settings faced by the interpreter when explaining the contents of the verses of the Holy Qur'an.

Therefore the guidance of the Qur'an voiced by interpretation must be the answer to every problem faced by society. The contextualization of the Qur'an through interpretation becomes a necessary thing. Interpretations that respond to factual conditions faced by interpreters are considered to be very instrumental in voicing the Qur'anic guidance as needed. Because the context of the revelation of the Qur'an to the prophet Muhammad. also related to every event that it faces [8].

As a holy book, the Qur'an contains ideals and reality [23]. Al-Qur'an becomes a dialogical product that results from dialogue that is built between text and reality, therefore alQur'an cannot be revealed in an empty space that has no relevance to the social situation when it was revealed [23]. Therefore the sociological aspect becomes the attention of the interpreter in explaining the Qur'an.

Because of the relevance to the social situation, the interpreter's attention to the condition of the community he witnessed directly will be able to influence it in producing interpretive 
work. From this it can be understood the emergence of tendencies or can also be called nuances of interpretations that result [24].

The interpretation of the Qur'an produced from interpreters carries its own nuance. The nuances of interpretation according to Islah Gusmian are defined as spaces that have a dominant level of tendency as the point of view of the product of interpretation presented. The nuances of this interpretation will then present so much the tendency of interpreters to verses that have specifications such as linguistic, social, theological, sufistic, psychological [24].

In the development of interpretation, interpretive activities that are present as an effort to contextualize texts developed by contemporary Muslim scholars are not inspirations that are considered new or appearing later. Even in other scientific traditions similar activities have also been carried out by Islamic fiqh mujtahids, Islamic jurisprudence.

Contextualization in the field of fiqh can be seen from the various schools of Islamic jurisprudence with different regional distribution. Even these regional differences also contribute to the style of fiqh thinking developed. In Indonesia, contextual fiqh thinking emerged, call it the Social Feeling Fiqh developed by K.H. M.A. Sahal Mahfudh [25]. Fiqh is developed by looking at social responses that continue to experience development. A dynamic and constantly changing society has an impact on scientific perspectives.

In interpretation, Muhammad Abduh had tried to respond to the community. He creates commentary works with a social nuance. The style he developed was done to avoid the appearance of the impression that the Koran had no connection with the historical roots of human life [24].

The verse's response to reality is one thing that actually helps one understand the Qur'anic text. How the text is spoken to to help explain the problems faced by the community. Or it could be that the Qur'an explains the messages it has in accordance with the circumstances of the people who are reading it.

The present social reality becomes the object of discussion by interpreters. The plurality of a nation actually becomes a wealth of interpretation because it can help the interpreter explain the texts conveyed by the Qur'an. Interpretation by exploring the potential of diversity by presenting a new paradigm of interpretation with a multicultural style can present interpretive texts that are responsive to cultural differences. So that in turn can create peace in the midst of cultural diversity and identity between them. Interpretative texts with multicultural features become guidelines for community life with a complex level of diversity.

Multicultural interpretation departs from the background of a multicultural Indonesian nation. Cultural differences become big capital in the effort to carry out interpretation activities. Because of the content and direction of one's written work, in this case an interpreter will always be influenced by the social context in which he explains the Qur'anic texts [26]. Producing interpretive works that are unique to Indonesia by considering the multicultural aspects that are owned will be able to increase knowledge for Indonesian Muslims. Furthermore, reading a commentary that has a multicultural style will help readers have an open and tolerant attitude and mutual respect for others. These ideals can be realized if from the text (interpretation) has created peace. WaAllahu a'lam.

\section{References}

[1] A. B. J. Al-Jazairi, Aysar al-Tafasir li Kalam al-'Aliyy al-Kabir. Madinah: Maktab hal-'Ulum wa al-Hikam, 2003.

[2] O. University, Oxford Advanced Leraners Dictionary. England: Oxford University Press. 
[3] N. Madjid, Islam Doktrin dan Peradaban. Jakarta: Paramadina, 2000.

[4] M. Q. Shihab, Membumikan Al-Qur'an. Bandung: Mizan, 2007.

[5] M. Q. Shihab, Rasionalitas Al-Qur'an, Studi Kritis Atas Tafsir Al-Manar. Jakarta: Lentera Hati, 2006.

[6] M. Amin, Empat Bingkai Kerukunan Nasional. Serang: Yayasan An-Nawawi, 2013.

[7] L. J. Moleong, Metodologi Penelitian Kualitatif. Bandung: Rosda Karya, 2007.

[8] T. A. Amal, Rekonstruksi Sejatah Al-Qur'an. Jakarta: Alvabet, 2005.

[9] M. A. Al-Shabuni, al-Tibyan fi 'Ulum al-Qur'an. Dar al-Mawahib al-Islamiyyah, 2016.

[10] N. H. A. Zayd, Tekstualitas Al-Qur'an, Terj, Khai. Yogyakarta: LKiS, 2005.

[11] Z. Zaidan, Tarikh Adab al-Lughah al- 'Arabiyyah. Bairut: Dar al-Fikr, 1996.

[12] F. Rahman, Tema-Tema Pokok Al-Qur'an. Bandung: Pustaka, 1996.

[13] Kementerian Agama RI, Al-Qur'an dan Tafsirnya. Jakarta, 2012.

[14] I. Katsir, Tafsir Al-Qur'an al- 'Azhim. Kairo: Dar al-Hadits, 2003.

[15] A. Reid, "Religious Pluralism or Conformity In Southeast Asia's Cultural Legacy," Stud. Islam., vol. 22, no. 3, 2015.

[16] A. Haromaini, "Mengenal Hermeneutika Melalui Muhammad Sahrur dan Hassan Hanafi," Rausyan Fikr, vol. 15, no. 1, 2019.

[17] I. J. Boullata, Al-Qur'an Yang Menakjubkan, Terj. Bach. Jakarta: Lentera Hati, 2008.

[18] A. H. Rasyidi, "Kajian Islamologi Tentang Tradisi Pembaharuan Dan Modernitas;Telaah Buku Dirasat Islamiyah Hassan Hanafi," J. Islam Nusant., vol. 1, no. 2, 2017.

[19] S. As-Shalih, Membahas Ilmu-ilmu al-Qur'an. Jakarta: Pustaka Firdaus, 2004.

[20] A. Saeed, Al-Qur'an Abad 21. Bandung: Mizan, 2016.

[21] S. Kazuo, Kiri Islam, Telaah Kritis Pemikiran Hassan Hanafi. Yogyakarta: LKiS, 2011.

[22] M. Abduh, Tafsir al-Qur'an al-Hakim. Kairo: Dar al-Manar, 1947.

[23] H. Al-Kaff, "Quo Vadis Islam Liberalisme Islam Indonesia," Kompas, Jakarta, 2011.

[24] I. Gusmian, Khazanah Tafsir Indonesia, Dari Hermeneutika Hingga Ideologi. Jakarta: Teraju, 2003.

[25] M. S. Mahfudh, Nuansa Figh Sosial. Yogyakarta: LKiS, 2012.

[26] K. Hidayat, Memahami Bahasa Agama, Sebuah Kajian Hermeneutik. 1996. 